\title{
Pengaruh Pengetahuan Anggaran, Partisipasi Masyarakat dan Transparansi Kebijakan Publik terhadap Fungsi Dewan dalam Pengawasan Anggaran Pendapatan dan Belanja Daerah (APBD)
}

\author{
Ferdinant Nuru \\ David P. E. Saerang \\ Jenny Morasa
}

\begin{abstract}
The purpose of this research is to examine the effect of the knowledge of budget, public participation and public policy transparency towards the local council function within budget control. The results shows that budgets knowledge, public participation and public policy transparency affect the council functions within local budget control. Only transparency of public policies that affect partially the council functions within regional budget control, while the budget knowledge and public participation did not affect the function of the local council within the budget control. The budget knowledge did not affect the council functions within budget control because it poorly supported by the competency level of councilors, while the public participation had no effect because the overall respondents answer can be concluded that public critique and suggestions is less accommodated especially public involvement in the budget advocacy.
\end{abstract}

Key words : The knowledge of budget, public participation, public policy transparency, the local council functions, regional budget control. 


\section{PENDAHULUAN}

\subsection{Latar Belakang Masalah}

Secara umum Anggaran Pendapatan dan Belanja Daerah (APBD) merupakan pernyataan tentang rencana pendapatan dan belanja daerah dalam periode tertentu (1 tahun). Fungsi APBD pada awalnya sebagai pedoman pemerintah daerah dalam mengelola keuangan daerah untuk satu periode. Sebelum anggaran dijalankan harus mendapat persetujuan dari Dewan Perwakilan Rakyat Daerah (DPRD) sebagai wakil rakyat, oleh karena itu fungsi anggaran juga sebagai alat pengawasan dan pertanggungjawaban terhadap kebijakan publik. Dengan melihat fungsi anggaran tersebut maka seharusnya anggaran merupakan power relation antara eksekutif, legislatif dan rakyat itu sendiri (Sopanah, 2005).

Salah satu aspek penting dalam rangka pelaksanaan otonomi daerah dan desentralisasi daerah adalah masalah pengelolaan keuangan secara khusus dan masalah Pengelolaan APBD secara umum. Untuk mewujudkan otonomi daerah dan desentralisasi yang luas, nyata, dan bertanggungjawab diperlukan manajemen keuangan daerah yang mampu mengontrol kebijakan keuangan daerah yang tertuang dalam APBD secara ekonomis, efisien, efektif, transparan, dan akuntabel.

Pengawasan anggaran yang dilakukan oleh dewan dipengaruhi oleh faktor internal dan faktor eksternal (Sopanah, 2005). Faktor internal adalah faktor yang dimiliki oleh dewan yang berpengaruh secara langsung terhadap pengawasan yang dilakukan oleh dewan, salah satunya adalah pengetahuan tentang anggaran. Sedangkan faktor eksternal adalah pengaruh dari pihak luar terhadap fungsi pengawasan yang akan memperkuat atau memperlemah fungsi pengawasan yang dilakukan oleh dewan, diantaranya adalah akuntabilitas publik, transparansi kebijakan publik dan partisipasi masyarakat.

Berdasarkan uraian serta penjelasan di atas, maka sangat jelas bahwa fungsi legislatif atau DPRD dalam pengawasan APBD sangat besar dan memiliki nilai yang sangat strategis untuk dapat mengontrol kebijakan APBD secara ekonomis, efisien, efektif, transparan, dan akuntabel. Namun kenyataan yang terjadi selama ini, bahwa masih banyak permasalahan dan kelemahan dalam pengelolaan APBD yang dilaksanakan lembaga eksekutif yang tidak dapat dikontrol dengan baik oleh lembaga legislatif karena masih rendahnya peranan legislatif atau DPRD dalam keseluruhan proses atau siklus anggaran, baik dalam hal perencanaan, pelaksanaan, pelaporan maupun pengawasan program kerja eksekutif. Rendahnya peran legislatif ini terjadi karena dipengaruhi oleh faktor-faktor yang telah diuraikan di atas yaitu pengetahuan tentang anggaran, partisipasi masyarakat dan transparansi kebijakan publik. Hal inilah yang menjadi pertimbangan peneliti untuk meneliti kembali faktor-faktor yang mempengaruhi fungsi Dewan dalam pengawasan APBD.

Berdasarkan latar belakang di atas, penulis memutuskan dalam penelitian ini mengangkat judul "Pengaruh Pengetahuan Anggaran, Partisipasi Masyarakat dan Transparansi Kebijakan Publik terhadap Fungsi Dewan dalam Pengawasan Anggaran Pendapatan dan Belanja Daerah (APBD)".

\subsection{Rumusan Masalah}

Berdasarkan latar belakang yang telah diuraikan di atas, maka peneliti merumuskan masalah penelitian sebagai berikut:

1. Apakah pengetahuan anggaran berpengaruh terhadap fungsi Dewan dalam pengawasan APBD pada DPRD Kota Sorong?

2. Apakah partisipasi masyarakat berpengaruh terhadap fungsi Dewan dalam pengawasan APBD pada DPRD Kota Sorong?

3. Apakah transparansi kebijakan publik berpengaruh terhadap fungsi Dewan dalam pengawasan APBD pada DPRD Kota Sorong? 
4. Apakah pengetahuan anggaran, partisipasi masyarakat dan transparansi kebijakan publik secara simultan berpengaruh terhadap fungsi Dewan dalam pengawasan APBD pada DPRD Kota Sorong?

\subsection{Tujuan Penelitian}

Berdasarkan pada rumusan masalah di atas maka, tujuan dari penelitian ini adalah:

1. Untuk mengetahui pengaruh pengetahuan anggaran terhadap fungsi Dewan dalam pengawasan APBD pada DPRD Kota Sorong.

2. Untuk mengetahui pengaruh partisipasi masyarakat terhadap fungsi Dewan dalam pengawasan APBD pada DPRD Kota Sorong.

3. Untuk mengetahui pengaruh transparansi kebijakan publik terhadap fungsi Dewan dalam pengawasan APBD pada DPRD Kota Sorong.

4. Untuk mengetahui pengaruh pengetahuan anggaran, partisipasi masyarakat dan transparansi kebijakan publik secara simultan terhadap fungsi Dewan dalam pengawasan APBD pada DPRD Kota Sorong.

\subsection{Manfaat Penelitian}

Hasil penelitian ini diharapkan sebagai sumbangan pikiran dan memberikan manfaat yang berarti, yaitu :

1. Bagi pemerintah daerah, diharapkan sebagai masukan dalam mendukung pelaksanaan otonomi daerah khususnya akan meningkatkan kinerja DPRD dalam pengawasan APBD dalam mewujudkan pemerintahan yang baik (good governace); sedangkan bagi partai politik dapat dijadikan acuan pada saat rekruitment anggota dewan dan pengembangan kader partai.

2. Bagi peneliti dapat menambah wawasan dan pengetahuan peneliti tentang sistem akuntansi sektor publik dan fungsi dewan dalam pengawasan Angaran Pendapatan dan Belanja Daerah (APBD).

3. Bagi para akademisi hasil penelitian ini diharapkan dapat memberikan kontribusi terhadap pengembangan literatur akuntansi sektor publik (ASP) terutama pengembangan sistem pengendalian manajeman sektor publik. Selanjutnya, dapat dijadikan sebagai acuan guna penelitian lanjutan.

\section{TINJAUAN PUSTAKA}

\subsection{Pengetahuan Anggaran}

Mahsun (2012 : 145), menyatakan bahwa anggaran adalah perencanaan keuangan untuk masa depan yang pada umumnya mencakup jangka waktu satu tahun dan dinyatakan dalam satuan moneter. Pengetahuan dewan tentang anggaran dapat diartikan sebagai pengetahuan dewan terhadap mekanisme penyusunan anggaran mulai dari tahap perencanaan, penyusunan, pelaksanaan dan pertanggungjawaban APBD serta pengetahuan dewan tentang peraturan perundangan yang mengatur pengelolaan keuangan daerah dan peraturan daerah tentang APBD.

\subsection{Partisipasi Masyarakat}

Partisipasi masyarakat dalam penganggaran harus dilakukan pada setiap tahapan dalam siklus anggaran mulai dari tahap persiapan anggaran (preparation), ratifikasi (approval/ratification), implementasi (implementation), dan pelaporan dan evaluasi (reporting and evaluation) (Mardiasmo, 2009: 70).

\subsection{Transparansi Kebijakan Publik}

Transparency merupakan salah satu Karakteristik Good Governance menurut United Nation Development Program (UNDP). Transparansi dibangun atas dasar kebebasan 
memperoleh informasi. Informasi yang berkaitan dengan kepentingan publik secara langsung dapat diperoleh oleh mereka yang membutuhkan, (Mardiasmo, 2009: 20).

\subsection{Fungsi DPRD sebagai Pengawas APBD}

Pengawasan merupakan tahap yang integral dari keseluruhan tahapan dalam proses penyusunan, pelaksanaan dan pelaporan pertanggungjawaban APBD. Pengawasan diperlukan pada setiap tahap bukan hanya pada tahap evaluasi saja (Mardiasmo, 2009). Pengawasan oleh dewan terhadap APBD dimulai pada saat proses penyusunan, pelaksanaan, perubahan dan pertanggungjawaban APBD.

\subsection{Penelitian Terdahulu}

Penelitian yang berkaitan dengan Anggaran dan Pengawasan APBD telah banyak dilakukan antara lain penelitian yang dilakukan oleh Warimon (2005) yang meneliti menegai "Pengaruh Partisipasi Masyarakat dan Transparansi Kebijakan Publik Terhadap Hubungan Antara Pengetahuan Dewan Tentang Anggaran Dengan Pengawasan Keuangan Daerah (APBD)". Dari hasil penelitian ini menyimpulkan bahwa (1) pengetahuan Dewan tentang anggaran berpengaruh positif signifikan terhadap pengawasan keuangan daerah (APBD) atau dengan kata lain semakin tinggi pengetahuan dewan tentang anggaran maka pengawasan keuangan daerah yang dilakukan oleh dewan akan semakin meningkat. (2) interaksi antara pengetahuan dewan tentang anggaran dengan partisipasi masyarakat berpengaruh negatif signifikan terhadap pengawasan APBD, (3) interaksi antara pengetahuan dewan tentang anggaran dengan transparansi kebijakan publik tidak berpengaruh positif signifikan terhadap pengawasan APBD, (4) interaksi antara pengetahuan dewan tentang anggaran dengan partisipasi masyarakat dan transparansi kebijakan publik tidak berpengaruh positif signifikan terhadap pengawasan APBD.

3. KERANGKA KONSEPTUAL

3.1. Kerangka Konseptual Penelitian

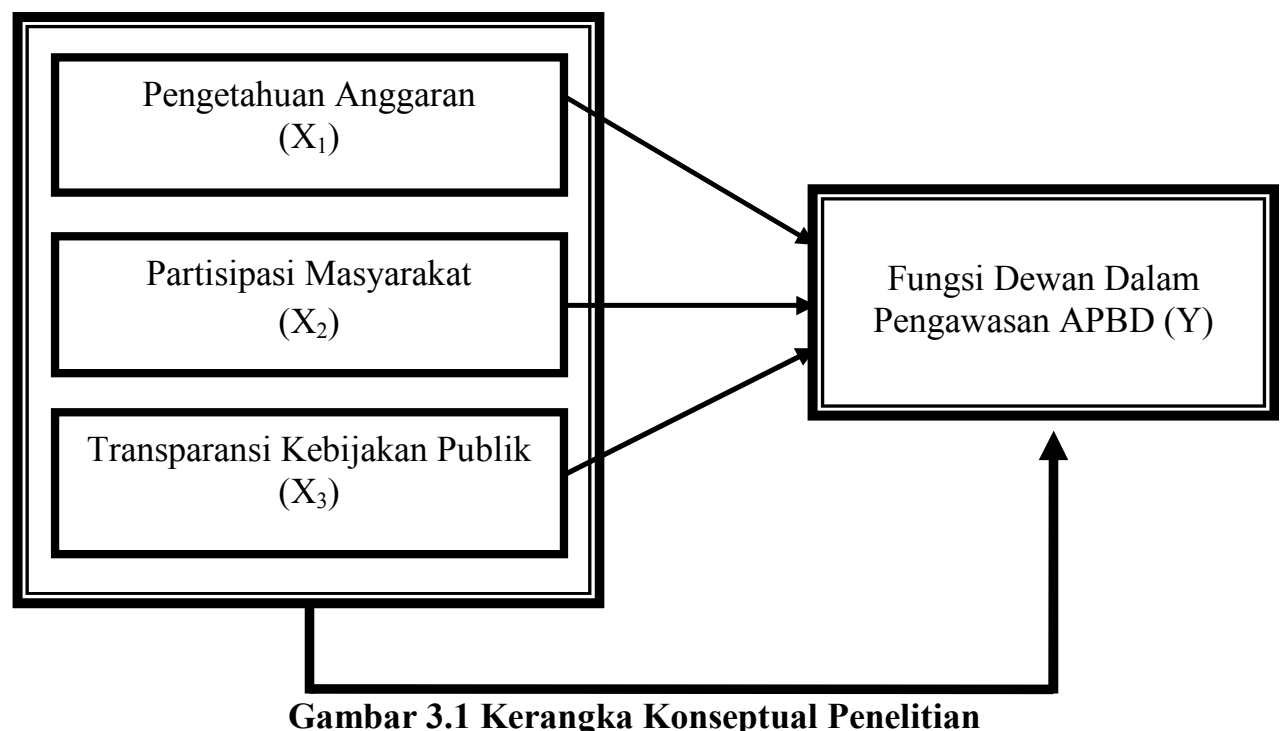

\subsection{Hipotesis}

H1 : Pengetahuan anggaran berpengaruh terhadap fungsi Dewan dalam pengawasan APBD pada DPRD Kota Sorong.

H2 : Partisipasi Masyarakat berpengaruh terhadap fungsi Dewan dalam pengawasan APBD pada DPRD Kota Sorong.

H3 : Transparansi kebijakan publik berpengaruh terhadap fungsi Dewan dalam pengawasan APBD pada DPRD Kota Sorong. 
H4 : Pengaruh Pengetahuan Anggaran, Partisipasi Masyarakat, dan Transparansi Kebijakan Publik terhadap fungsi Dewan dalam pengawasan APBD pada DPRD Kota Sorong.

\section{METODE PENELITIAN}

\subsection{Jenis/Rancangan Penelitian yang Digunakan}

\begin{tabular}{|l|c|c|c|c|}
\hline & $\left(\mathrm{X}_{1}\right)$ & $\left(\mathrm{X}_{2}\right)$ & $\left(\mathrm{X}_{3}\right)$ & $(\mathrm{Y})$ \\
\hline Corrected Item-Total Correlation P1 & .566 & .622 & .579 & .597 \\
\hline Corrected Item-Total Correlation P2 & .782 & .490 & .432 & .658 \\
\hline Corrected Item-Total Correlation P3 & .684 & .490 & .553 & .492 \\
\hline Corrected Item-Total Correlation P4 & .615 & .604 & .719 & .522 \\
\hline Corrected Item-Total Correlation P5 & .640 & .475 & .775 & .724 \\
\hline Corrected Item-Total Correlation P6 & .422 & .735 & .720 & .476 \\
\hline Corrected Item-Total Correlation P7 & .825 & .689 & .446 & .725 \\
\hline Corrected Item-Total Correlation P8 & .474 & .733 & .694 & .365 \\
\hline Corrected Item-Total Correlation P9 & .580 & .663 & .442 & .492 \\
\hline Corrected Item-Total Correlation P10 & .738 & .475 & .327 & .339 \\
\hline Corrected Item-Total Correlation P11 & .605 & .725 & .448 & .381 \\
\hline Corrected Item-Total Correlation P12 & .471 & .541 & .557 & .614 \\
\hline Corrected Item-Total Correlation P13 & .449 & .663 & .849 & .415 \\
\hline Corrected Item-Total Correlation P14 & .843 & .539 & .652 & .302 \\
\hline Cronbach's Alpha & .759 & .756 & .754 & .740 \\
\hline
\end{tabular}

Jenis penelitian ini dapat dikatakan sebagai penelitian kausal yaitu untuk melihat hubungan beberapa variabel yang belum pasti. Penelitian ini menggunakan jenis data kualitatif yang dikuantitatifkan yaitu data mengenai pengetahuan tentang anggaran, latar belakang pendidikan, tingkat pendidikan dan pengalaman politik terhadap kinerja DPRD dalam pengawasan pengelolaan keuangan daerah/APBD yang diangkakan (scoring) dengan menggunakan skala likert. Sumber data dalam penelitian ini berasal dari responden yaitu seluruh anggota DPRD Kota Sorong periode 2009-2014.

\subsection{Populasi, Sampel, Besar Sampel, dan Teknik Pengambilan Sampel}

Populasi penelitian merupakan keseluruhan (universum) dari objek penelitian yang dapat berupa manusia, hewan, tumbuh-tumbuhan, udara, gejala, nilai, peristiwa, sikap hidup, dan sebagainya, sehingga objek-objek ini dapat menjadi sumber data penelitian, (Masyhuri, Zainuddin M., 2009 : 151). Populasi dalam penelitian ini adalah seluruh anggota dewan yang berada di Lembaga Dewan Perwakilan Rakya Daerah (DPRD) Kota Sorong sebanyak 30 orang.

Sedangkan sampel adalah suatu himpunan bagian (subset) dari unit populasi. Metode pengambilan sampel adalah observasi, wawancara dan sensus atau kuesioner, yang mana seluruh populasi yaitu 30 orang anggota DPRD Kota Sorong dijadikan sebagai sampel.

\subsection{Cara Pengolahan dan Analisis Data}

Pengolahan data dalam penelitian ini dilakukan dengan tahap-tahap sebagai berikut:

1. Menentukan profil responden.

2. Pengujian kualitas data

3. Pengujian Gejala Penyimpangan Asumsi Klasik.

4. Pengujian Hipotesis

5. Menentukan Koefisien Korelasi dan Determinasi

6. analisis regresi linier berganda 


\section{ANALISIS DAN PEMBAHASAN HASIL PENELITIAN}

\subsection{Uji Validitas dan Reliabilitas Data}

Hasil uji validitas dan reliabilitas untuk pertanyaan 1-14 untuk variabel $\mathrm{X}_{1} \mathrm{X}_{2} \mathrm{X}_{3}$ dan $\mathrm{Y}$, mempunyai nilai korelasi di atas 0,30 dan cronbach alpha 0,743 . Semua dinyatakan reliabel dan valid.

\subsection{Uji Asumsi Klasik}

4. Uji Normalitas

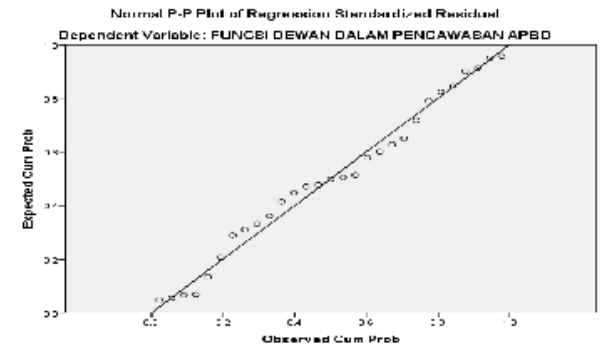

(Sumber : Data Hasil Olahan SPSS)

Gambar 5.1 Uji Normalitas

Gambar 5.1 menunjukkan bahwa grafik Normal P-P of regression standardized residual memenuhi asumsi normalitas dimana penyebaran data di sekitar dan mengikuti arah garis diagonal grafik tersebut.

\section{Uji Heteroskedastisitas}
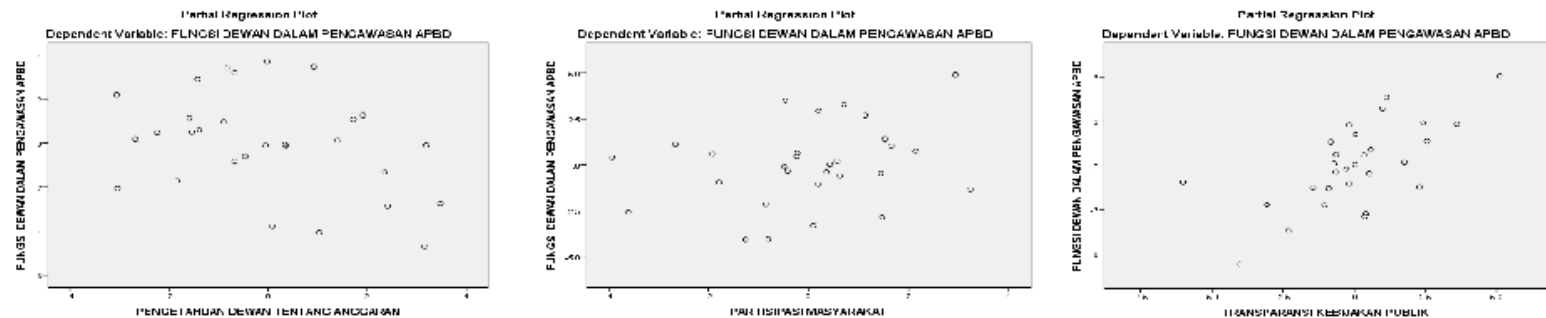

(Sumber : Data Hasil Olahan SPSS)

Gambar 5.2 Uji Heteroskedastisitas

Pada gambar 5.2 dapat dilihat bahwa titik-titik tidak membentuk suatu pola yang jelas, serta titik-titik menyebar di atas dan di bawah angka 0 (nol) pada sumbu Y, hal ini membuktikan tidak terjadi heteroskedastisitas.

\section{Uji Multikoleniaritas}

Tabel 5.2 Hasil uji multikolinearitas

\begin{tabular}{|ll|c|c|}
\hline \multirow{2}{*}{ Model } & \multicolumn{2}{|c|}{ Collinearity Statistics } \\
\cline { 2 - 3 } & Tolerance & VIF \\
\hline $1 \quad$ (Constant) & & \\
& Pengetahuan Dewan Tentang Anggaran & .120 & 8.326 \\
& Partisipasi Masyarakat & .109 & 9.142 \\
\multicolumn{2}{|l|}{ Transparansi Kebijakan Publik } & .192 & 5.209 \\
\hline
\end{tabular}

(Sumber : Data Hasil Olahan SPSS)

Berdasarkan hasil coefficients yang terdapat pada tabel 5.2 dapat dilihat pada output coefficients model, dikatakan tidak terjadi gejala multikolinearitas jika VIF $<10$ dan nilai tolerance $>$ 0,10 . 


\subsection{Koefisien Korelasi (r)}

Tabel 5.3 Koefisien Korelasi

\begin{tabular}{|ll|r|}
\hline & & $\begin{array}{c}\text { Fungsi Dewan Dalam } \\
\text { Pengawasan APBD }\end{array}$ \\
\hline Pearson & Fungsi Dewan Dalam Pengawasan APBD & 1.000 \\
Correlation & Pengetahuan Dewan Tentang Anggaran & .693 \\
& Partisipasi Masyarakat & .769 \\
& Transparansi Kebijakan Publik & .857 \\
\hline Sig. (1- & Fungsi Dewan Dalam Pengawasan APBD & .000 \\
tailed) & Pengetahuan Dewan Tentang Anggaran & .000 \\
& Partisipasi Masyarakat & .000 \\
& Transparansi Kebijakan Publik & 29 \\
\hline N & Fungsi Dewan Dalam Pengawasan APBD & 29 \\
& Pengetahuan Dewan Tentang Anggaran & 29 \\
& Partisipasi Masyarakat & 29 \\
\hline
\end{tabular}

(Sumber : Data Hasil Olahan SPSS)

Hasil olahan data menunjukkan bahwa variabel Pengetahuan Dewan Tentang Anggaran $\left(\mathrm{X}_{1}\right)$ mempunyai korelasi yang bersifat kuat, positif dan signifikan dengan fungsi dewan dalam pengawasan APBD (Y). Untuk variabel Partisipasi Masyarakat $\left(\mathrm{X}_{2}\right)$ mempunyai korelasi yang bersifat kuat, positif dan signifikan dengan fungsi dewan dalam pengawasan APBD (Y). Untuk variabel Transparansi Kebijakan Publik $\left(\mathrm{X}_{3}\right)$ mempunyai korelasi yang bersifat sangat kuat, positif dan signifikan dengan fungsi dewan dalam pengawasan APBD (Y).

\subsection{Koefisien Determinasi $\left(\mathbf{R}^{2}\right)$}

Tabel 5. Hasil uji koefisen korelasi dan determinasi

\begin{tabular}{|c|c|c|c|c|}
\hline Model & $\mathrm{R}$ & R Square & $\begin{array}{c}\text { Adjusted R } \\
\text { Square }\end{array}$ & $\begin{array}{c}\text { Std. Error of the } \\
\text { Estimate }\end{array}$ \\
\hline 1 & $.876^{\mathrm{a}}$ & .768 & .740 & 2.248 \\
\hline
\end{tabular}

(Sumber : Data Hasil Olahan SPSS)

Dengan melihat tabel ouput SPSS model Summary maka dapat diketahui bahwa besarnya nilai koefisien determinasi $\left(\mathrm{R}^{2}\right)$ terlihat dari nilai Adjusted $R$ Square karena penelitian ini memiliki lebih dari satu variabel bebas yaitu sebesar 0,768 atau $76.8 \%$, sedangkan $23,2 \%$ dipengaruhi oleh variabel lain yang tidak dimasukkan dalam model penelitian ini.

\subsection{Analisis Regresi Linear Berganda}

$$
Y=14,567-0.431 X_{1}+0.361 X_{2}+0.831 X_{3}+e
$$

Tabel. 5.5 Koefisien Regresi

\begin{tabular}{|ll|r|r|}
\hline \multirow{2}{*}{ Model } & & \multicolumn{2}{|c|}{ Unstandardized Coefficients } \\
\cline { 3 - 4 } & & \multicolumn{1}{|c|}{$\mathrm{B}$} & \multicolumn{2}{|c|}{ Std. Error } \\
\hline & (Constant) & 14.567 & 5.340 \\
& Pengetahuan Dewan Tentang Anggaran & -.431 & .225 \\
& Partisipasi Masyarakat & .361 & .249 \\
& Transparansi Kebijakan Publik & .831 & .192 \\
& Pengetahuan Dewan Tentang Anggaran & & \\
& &
\end{tabular}

(Sumber : Data Hasil Olahan SPSS)

Konstanta $\alpha$ sebesar 14,567 memberikan pengertian bahwa jika pengetahuan anggaran (X1), Partisipasi masyarakat (X2), dan transparansi kebijakan publik (X3) sama dengan nol (0), maka efektivitas fungsi dewan dalam pengawasan APBD di DPRD Kota Sorong adalah 14,567 satuan skor.

Variabel pengetahuan anggaran (X1), memiliki nilai koefisien regresi ( $\beta$ ) sebesar $-0,431$, ini berarti bahwa jika variabel lain nilainya tetap atau tidak berubah, maka setiap kenaikan 1 poin $(1 \%)$ variabel pengetahuan anggaran (X1) maka fungsi dewan dalam pengawasan APBD akan berkurang 
sebesar 0,431 dari kondisi sebelumnya. Koefisien variabel pengetahuan anggaran (X1) bernilai negatif, artinya terdapat hubungan negatif antara (X1) pengetahuan anggaran dengan (Y) fungsi dewan dalam pengawasan APBD. Artinya bahwa semakin berkurang nilai pengetahuan dewan tentang anggaran, maka akan berdampak pada lemahnya pengawasan terhadap APBD di DPRD Kota Sorong.

Variabel Partisipasi masyarakat (X2), memiliki nilai koefisien regresi $(\beta)$ sebesar 0,361 , ini berarti bahwa jika variabel lain nilainya tetap atau tidak berubah, maka setiap kenaikan 1 poin $(1 \%)$ variabel Partisipasi masyarakat (X2), akan meningkatkan nilai fungsi dewan dalam pengawasan APBD sebesar 0,361 dari kondisi sebelumnya. Koefisien variabel Partisipasi masyarakat (X2), bernilai positif, artinya terdapat hubungan positif antara (X2) Partisipasi masyarakat dengan (Y) fungsi dewan dalam pengawasan APBD. Artinya bahwa jika Partisipasi masyarakat (X2) semakin meningkat maka akan meningkatkan fungsi dewan dalam pengawasan APBD (Y) di DPRD Kota.

Variabel transparansi kebijakan publik (X3), memiliki nilai koefisien regresi ( $\beta$ ) sebesar 0,831 , ini berarti bahwa jika variabel lain nilainya tetap atau tidak berubah, maka setiap kenaikan 1 poin (1\%) variabel transparansi kebijakan publik (X3), akan meningkatkan nilai fungsi dewan dalam pengawasan APBD sebesar 0,831 dari kondisi sebelumnya. Koefisien variabel transparansi kebijakan publik (X3), bernilai positif, artinya terdapat hubungan positif antara (X3) transparansi kebijakan publik dengan (Y) fungsi dewan dalam pengawasan APBD. Artinya bahwa semakin meningkat nilai transparansi kebijakan publik (X3), maka akan meningkatkan fungsi dewan dalam pengawasan APBD (Y) di DPRD Kota Sorong.

5.6. Pengujian Hipotesis (Uji F)

Tabel 5.6 Analysis Of Variance

\begin{tabular}{|ll|r|r|r|c|c|}
\hline & Model & \multicolumn{1}{c|}{$\begin{array}{c}\text { Sum of } \\
\text { Squares }\end{array}$} & df & Mean Square & F & Sig. \\
\hline 1 & Regression & 418.935 & 3 & 139.645 & 27.625 & $.000^{\mathrm{a}}$ \\
& Residual & 126.376 & 25 & 5.055 & & \\
Total & 545.310 & 28 & & & \\
\hline
\end{tabular}

(Sumber : Data Hasil Olahan SPSS)

Dari tabel 5.25 diketahui nilai $\mathrm{F}_{\text {hitung }}=27,625$. Angka tersebut lebih besar dari $\mathrm{F}_{\text {tabel }}=2,991$ $\left(\mathrm{F}_{\text {hitung }}>\mathrm{F}_{\text {tabel }}\right.$ atau $\left.27,625>2,991\right)$ pada tingkat signifikansi 0,000 lebih kecil dari 0,05. Dengan demikian maka dapat disimpulkan bahwa $\mathrm{H}_{\mathrm{o}}$ ditolak dan $\mathrm{H}_{\mathrm{a}}$ diterima. Artinya bahwa, Pengetahuan Anggaran $\left(\mathrm{X}_{1}\right)$, Partisipasi Masyarakat $\left(\mathrm{X}_{2}\right)$ dan Transparansi Kebijakan Publik $\left(\mathrm{X}_{3}\right)$, secara bersamasama berpengaruh terhadap Fungsi Dewan Dalam Pengawasan APBD (Y).

\subsection{Pengujian Hipotesis (Uji t)}

\begin{tabular}{|l|r|r|r|r|}
\hline \multirow{2}{*}{ Model } & \multicolumn{2}{|c|}{ Tabel 5.7 Uji t } & Standardized Coeffi-cients & \multirow{2}{*}{$\mathrm{t}$} \\
\cline { 2 - 4 } & \multicolumn{1}{|c|}{ U } & Std. Error & Beta & 2.728 \\
(Constant) & 14.567 & 5.340 & -1.920 \\
Pengetahuan Dewan Tentang & -.431 & .225 & -.533 \\
Anggaran & & & \\
Partisipasi Masyarakat & .361 & .249 & .423 \\
Transparansi Kebijakan Publik & .831 & .192 & .949 & 4.451 \\
\hline
\end{tabular}

(Sumber : Data Hasil Olahan SPSS)

Dari tabel 5.26 dapat diketahui hasil uji $t$ untuk masing-masing variabel secara parsial yaitu, nilai koefisien regresi $X_{1}$ memiliki tingkat signifikansi 0,066, nilai ini lebih besar dari 0,05 (sig $>\alpha$ atau $0,066>0,05$ ); apabila menggunakan nilai $\mathrm{t}_{\text {-hitung }}$ dibandingkan dengan $\mathrm{t}_{\text {-tabel }}$ dapat diketahui bahwa nilai $t$ - hitung sebesar $-1,920$ lebih kecil dari nilai $t_{\text {-tabel }}$ sebesar 2,060 $\left(\mathrm{t}_{\text {-hitung }}<\mathrm{t}_{\text {tabel }}\right.$ atau $-1,920$ $<2,060)$. Hal ini berarti bahwa Variabel Pengetahuan Anggaran $\left(X_{1}\right)$ tidak berpengaruh terhadap Fungsi Dewan Dalam Pengawasan APBD di DPRD Kota Sorong.

Nilai koefisien regresi X2 memiliki tingkat signifikansi 0,159, nilai ini lebih besar dari 0,05 (sig $>\alpha$ atau $0,159>0,05$ ); apabila menggunakan nilai $t_{\text {-hitung }}$ dibandingkan dengan $t_{\text {tabel }}$ dapat diketahui bahwa nilai $\mathrm{t}_{\text {hitung }}$ sebesar 1,451 lebih kecil dari nilai $\mathrm{t}_{\text {tabel }}$ sebesar 2,060 $\left(\mathrm{t}_{\text {-hitung }}<\mathrm{t}_{\text {-tabel }}\right.$ atau $1,451<2,060)$. Hal ini berarti bahwa Variabel Partisipasi Masyarakat $\left(\mathrm{X}_{2}\right)$ tidak berpengaruh terhadap Fungsi Dewan Dalam Pengawasan APBD di DPRD Kota Sorong. 
Nilai koefisien regresi X3 memiliki tingkat signifikansi 0,014, nilai ini lebih kecil dari 0,05 (sig $<\alpha$ atau $0,014<0,05$ ); apabila menggunakan nilai $\mathrm{t}_{\text {-hitung }}$ dibandingkan dengan $\mathrm{t}_{\text {-tabel }}$ dapat diketahui bahwa nilai $t_{\text {-hitung }}$ sebesar 2,658 lebih besar dari nilai $t_{\text {-tabel }}$ sebesar 2,060 $\left(\mathrm{t}_{\text {-hitung }}>\mathrm{t}_{\text {-tabel }}\right.$ atau 2,658 $>$ 2,060). Hal ini berarti bahwa Variabel Transparansi Kebijakan Publik $\left(\mathrm{X}_{3}\right)$ berpengaruh terhadap Fungsi Dewan Dalam Pengawasan APBD di DPRD Kota Sorong.

\subsection{Pembahasan}

1. Pengetahuan anggaran tidak berpengaruh terhadap fungsi Dewan dalam pengawasan APBD pada DPRD Kota Sorong.

Pengetahuan anggaran tidak berpengaruh terhadap fungsi dewan dalam pengawasan APBD terjadi karena kurang didukung oleh pemahaman anggota dewan mengenai penganggaran.

\section{Partisipasi Masyarakat tidak berpengaruh terhadap fungsi Dewan dalam pengawasan} APBD pada DPRD Kota Sorong.

Keterlibatan masyarakat yang setiap tahunnya dilakukan melalui musrenbang untuk menjaring aspirasi masyarakat sudah berjalan dengan baik. Problem nyata yang dihadapi adalah ternyata mekanisme partisipasi yang ada tidak cukup memberikan ruang apresiatif dari masyarakat karena patisipasi yang dijalankan hanyalah partisipasi yang semu, simbolis penuh dengan manipulasi karena aturan-aturan itu tidak bisa menjamin proses penganggaran, berdasarkan people need assessment.

3. Transparansi Kebijakan Publik berpengaruh terhadap fungsi Dewan dalam pengawasan APBD pada DPRD Kota Sorong.

Transparan merupakan prinsip keterbukaan yang memungkinkan masyarakat untuk mengetahui dan mendapatkan akses informasi seluas-luasnya tentang keuangan daerah.

4. Pengetahuan anggaran, Partisipasi Masyarakat, dan Transparansi Kebijakan Publik berpengaruh terhadap fungsi Dewan dalam pengawasan APBD pada DPRD Kota Sorong.

Hasil penelitian ini mendukung penelitian yang dilakukan Isma Coryanata. (2007), Wardayani (2010), Sari (2010) menyimpulkan bahwa secara simultan pengetahuan dewan tentang anggaran, partisipasi masyarakat, dan transparansi kebijakan publik berpengaruh signifikan terhadap kinerja DPRD dalam pengawasan keuangan daerah. Namun hasil penelitian ini tidak sejalan dengan penelitian yang dilakukan oleh Werimon (2005) dan Winarna \& Murni (2007) menyatakan bahwa interaksi antara pengetahuan dewan tentang anggaran dengan partisipasi masyarakat dan transparansi kebijakan publik tidak berpengaruh positif signifikan terhadap pengawasan APBD.

6. PENUTUP

6.1. Simpulan berikut.

Dari hasil penelitian dan pembahasan maka dapat disimpulkan beberapa kesimpulan sebagai

3. Pengetahuan Anggaran (X1), tidak berpengaruh terhadap fungsi dewan dalam pengawasan APBD (Y) adalah sebesar koefisien regresi $(\beta)-0,431$, dengan nilai $t_{- \text {hitung }}<t_{\text {-tabel }}$ atau $-1,920$ $<2,060$. Artinya bahwa jika variabel lain nilainya tetap atau tidak berubah, maka setiap kenaikan 1 poin (1\%) variabel pengetahuan anggaran maka fungsi dewan dalam pengawasan APBD akan berkurang sebesar 0,431 dari kondisi sebelumnya. Koefisien variabel pengetahuan anggaran bernilai negatif, artinya terdapat hubungan negatif antara pengetahuan anggaran dengan fungsi dewan dalam pengawasan APBD.

4. Partisipasi Masyarakat (X2), tidak berpengaruh terhadap fungsi dewan dalam pengawasan APBD (Y) adalah sebesar koefisien regresi $(\beta)$ 0,361 dengan nilai $t_{\text {-hitung }}<t_{\text {-tabel }}(1,451<$ 2,060). Artinya bahwa jika variabel lain nilainya tetap atau tidak berubah, maka setiap kenaikan 1 poin (1\%) variabel Partisipasi masyarakat, akan meningkatkan nilai fungsi dewan dalam pengawasan APBD sebesar 0,361 dari kondisi sebelumnya. Koefisien variabel Partisipasi masyarakat bernilai positif, artinya terdapat hubungan positif antara Partisipasi masyarakat dengan fungsi dewan dalam pengawasan APBD.

5. Transparansi Kebijakan Publik (X3), berpengaruh terhadap fungsi dewan dalam pengawasan APBD (Y) adalah sebesar koefisien regresi $(\beta)$ 0,831, dengan nilai $t_{- \text {hitung }}>t_{\text {tabel }}$ atau 2,658 $>$ 2,060. Artinya bahwa jika variabel lain nilainya tetap atau tidak berubah, maka setiap kenaikan 1 poin (1\%) variabel transparansi kebijakan publik, akan meningkatkan nilai fungsi dewan dalam pengawasan APBD sebesar 0,831 dari kondisi sebelumnya. Koefisien variabel 
transparansi kebijakan publik, bernilai positif, artinya terdapat hubungan positif antara transparansi kebijakan publik dengan fungsi dewan dalam pengawasan APBD.

6. Secara bersama-sama Pengetahuan Anggaran (X1), Partisipasi Masyarakat (X2), dan Transparansi Kebijakan Publik (X3) berpengaruh terhadap fungsi dewan dalam pengawasan APBD (Y) dengan nilai $\mathrm{F}_{\text {hitung }}>\mathrm{F}_{\text {tabel }}$ atau 27,625 $>2$,991, pada tingkat signifikansi 0,05 .

7. Kontribusi dari pengetahuan anggaran $\left(\mathrm{X}_{1}\right)$, partisipasi masyarakat $\left(\mathrm{X}_{2}\right)$, dan transparansi kebijakan publik $\left(\mathrm{X}_{3}\right)$ terhadap variasi naik turunnya fungsi dewan dalam pengawasan APBD di Kota Sorong adalah sebesar koefisien determinasi $\mathrm{R}^{2}=0.740$ atau $74 \%$. sedangkan sisanya sebanyak $26 \%$ dijelaskan oleh variabel lain yang tidak dimasukkan dalam model penelitian ini.

6.2. Saran

Dari hasil penelitian ini penulis menyarankan agar supaya sebagai berikut.

1. Untuk meningkatkan fungsi DPRD di bidang pengawasan sangat diperlukan pengetahuan dan kemampuan tentang anggaran, maka disarankan agar seluruh anggota DPRD diberikan pelatihan guna meningkatkan kemampuan DPRD dalam pengawasan APBD, dan secara khusus bagi anggota DPRD yang berhubungan dengan pengawasan dan anggaran.

2. Untuk memudahkan fungsi pengawasan yang bersifat kebijakan, sebaiknya DPRD memakai tenaga ahli yang memiliki kemampuan di bidangnya masing-masing yang bertugas melakukan pengkajian guna memberikan input. Tenaga ahli ini dapat diambil dari perguruan tinggi yang memang ahli di bidangnya. Dengan menggunakan hasil kajian ini diharapkan DPRD tidak salah dalam melaksanakan fungsi dan tugas pokoknya.

\section{DAFTAR PUSTAKA}

Arif B, Muchis, Iskandar, (2009) Akuntansi Pemerintahan, Penerbit Akademia, Jakarta

BAPEDA Kota Sorong, 2010, Profil Kota Sorong

Coryanata I. 2007, Akuntabilitas, Partisipasi Masyarakat, Dan Transparansi Kebijakan Publik Sebagai Pemoderating Hubungan Pengetahuan Dewan Tentang Anggaran Dan Pengawasan Keuangan Daerah (APBD), Simposium Nasional Akuntansi X, Unhas Makasar

Mardiasmo, (2009); Akuntansi Sektor Publik, Edisi IV, Penerbit ANDI Yogyakarta.

Mahsun, Moh. (2012) Pengukuran Kinerja Sektor Publik, Edisi Pertama, Penerbit BPFE Yogyakarta., Cetakan Ketiga Januari 2012.

Masyhuri, Zainuddin, M., Metodologi Penelitian Pendekatan Praktis dan Aplikatif, Cetakan kedua, Penerbit PT. Refika Aditama Bandung, 2009.

Nafarin, M., (2004) Penganggaran Perusahaan, Edisi Revisi, Penerbit Salemba Empat.

Nordiawan D. et. al, 2012, Putra I.S dan Rahmawati M. Akuntansi Pemerintahan, Penerbit Salemba Empat

Nordiawan D. dan Hertianti A., 2012, Akuntansi Sektor Publik, Edisi 2, Penerbit Salemba Empat

Riduwan, H. Sunarto, (2009), Pengantar Statitika, Penerbit ALFABETA Bandung

Republik Indonesia, 1999, Undang-Undang No. 22 Tahun 1999 tentang Pemerintah Daerah

Republik Indonesia, 1999, Undang-Undang No.25 Tahun 1999 tentang Perimbangan Keuangan antara Pemerintah Pusat dan Daerah.

Sari I. 2010, Pengaruh Personal Background dan Political Background Serta Pengetahuan Dewan Tentang Anggaran Terhadap Kinerja DPRD Dalam Pengawasan Keuangan Daerah/APBD

Sopanah, 2005, Pengaruh Akuntabilitas Publik, Partisipasi Masyarakat Dan Transparansi Kebijakan Publik Terhadap Hubungan Antara Pengetahuan Dewan Tentang Anggaran Dengan Pengawasan Keuangan Daerah (APBD) Jurnal Logos, Vol 3 No. 1 Juli 2005.

Sarjono, Haryadi \& Winda Julianita. 2011. SPSS vs LISREL Sebuah Pengantar, Aplikasi untuk Riset. Jakarta : Salemba Empat. 
Wahjono, S.I., 2006, Perilaku Organisasi, penerbit Graha Ilmu

Wardayani, 2010, Pengaruh Pengetahuan Dewan Tentang Anggaran, Partisipasi Masyarakat dan Transparansi Kebijakan Publik Terhadap Kinerja DPRD Dalam Pengawasan Keuangan Daerah Dengan Komitmen Profesional Sebagai Variabel Moderasi.

Weney M., 2012, Pengaruh Partisipasi Penyusunan Anggaran, Kepuasan Kerja, Budaya Organisasi Terhadap Kinerja Aparatur SKPD

Werimon S, 2005, Pengaruh Partisipasi Masyarakat Dan Transparansi Kebijakan Publik Terhadap Hubungan Antara Pengetahuan Dewan Tentang Anggaran Dengan Pengawasan Keuangan Daerah (APBD)

Werimon S, et al., 2007, Ghozali dan Nazir Moh., Pengaruh Partisipasi Masyarakat Dan Transparansi Kebijakan Publik Terhadap Hubungan Antara Pengetahuan Dewan Tentang Anggaran Dengan Pengawasan Keuangan Daerah (APBD, Simposium Nasional Akuntansi $\mathrm{X}$, Unhas Makasar.

Winarna J dan S. Murni. 2007, Pengaruh Personal Background, Political Background dan Pengetahuan Dewan Tentang Anggaran Terhadap Peran DPRD Dalam Pengawasan Keuangan Daerah, Simposium Nasional Akuntansi X, Unhas Makasar.

Wibowo. A.E., 2012, Aplikasi Praktis SPSS Dalam Penelitian, Penerbit Gaya Media Yogyakarta.

Cendrawasi Pos, (Keerom, Papua) Kamis, 01 Maret 2012 , 18:12:00

Suara Karya (Sorong-Papua Barat), 12 September 2006 